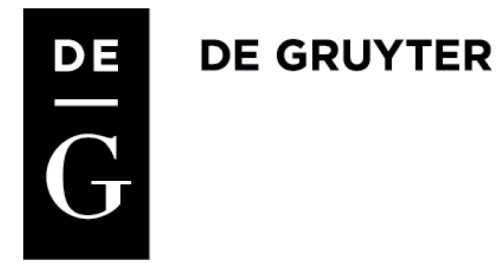

Jan Miłosz (Adam Mickiewicz University, Poznań)

\title{
BLACK MARKET - \\ FINANCIAL CRIMES COMMITTED FOR PERSONAL PURPOSES
}

In socialist Poland, in the reality of centrally planned economy, average citizens experienced chronic deficits of basic commodities. Although the intensity of the problem varied, at no time could one say that the official market fully satisfied the demand for basic or luxurious goods sought by citizens. On the one hand, the market was steered manually, prices were set and kept on the same level for many years, and the volume of production and its cost was centrally planned, but on the other hand, salaries in national companies were raised, which resulted in unsatisfied demand for the goods that the official market lacked. How, then, did average citizens deal with these problems? How, by committing more or less serious financial crimes, did they become players in the black market game, the stake of which was satisfying their own needs? This article attempts at describing the situation in this specific market in various periods of socialist Poland. It also tries to demonstrate which products were the most desirable and most often sold in the black market. Most citizens of socialist Poland, knowing that their behavior is against the law, limited their participation in the black market to purchasing or selling the most urgently needed products.

Keywords: black market, gold, currency, smuggle, speculation.

doi:10.1515/sho-2016-0004

\section{INTRODUCTION}

One of the definitions of black market describes it as:

[...] illegal or secret trade carried out when transactions are subject to control and regulation. (...) It develops when the supply of certain products, despite being regulated by legal provisions, does not satisfy the demand" [Encyklopedia historii gospodarczej do roku 1945 [Encyclopedia of Economic History 1981: 114]. 
Poles started to prepare for living in the reality of market deficits at the outbreak of the Second World War. Of course, the part of the population that ended up under the German occupation was doomed to play the role of "subhumans", who, according to Nazi racial policy, did not need that many basic commodities to perform work required by the "superhumans" and their "Thousand-year Reich". Those citizens of the Second Polish Republic who found themselves in territories occupied by the USSR, got a quick course on how to live in a centrally planned economy in order to be able to satisfy their basic needs, as early as 1939. Between 1941 (after the attack of the Third Reich on the Soviet Union) and mid-1944, the inhabitants of eastern parts of Poland who had managed to avoid Soviet deportations lived under the Nazi war economy. In Poland, in the years 1944 and 1945, the communist government started to form a new economic reality, based on the system already existing in the USSR. It had two basic features: the social (national and cooperative) ownership of economic entities, and the central planning of economic activities of the state. In Poland, throughout the whole period of centrally planned economy, a private sector, which operated more or less "successfully", existed beside the national and cooperative economic entities. This sector comprised both private farms and economic operators functioning in other sectors of the economy, such as private trade, manufacturing and craftsmanship. ${ }^{1}$ During the five years of occupation Poles had to cope with limited access to even those products which satisfied their essential needs. Once the occupation was over, they wanted to get a taste of normal life quickly. However, the situation in the country, destroyed by war and occupation, was far from what they remembered from pre-war days.

${ }^{1}$ Despite the efforts to limit private agriculture through intensive collectivization, the private sector endured the toughest period of the late 1940s and early 1950s, and then gradually regained the ability to function as one of the elements of centrally planned economy. In the years 1952-1955, the number of farming cooperatives grew to 9,800, and their area of production was approx. 1.6 million hectares - only $9.2 \%$ of all agricultural land. [Nowa Encyklopedia Powszechna PWN (PWN Universal Encyclopedia) 2004: 449-450]. As to trade, after the so-called "battle for trade" in the years 1947-1948 and subsequent trade nationalization, private trade started to develop again after 1956, firstly in markets, public squares and small shops, and later, in the 1970s, in the form of shops and bistros rented to private operators by national companies and cooperatives. Apart from agriculture and small trade, also craftsmanship and small industry defied nationalization, and in 1957 only there were 190,000 operators registered, including 134,000 craft shops, 27,000 small stores, 3,000 larger manufacturing plants and around 18,000 transportation companies (private taxis) [Pick D. 2003: 30]. 
In his book Tylnymi drzwiami. Czarny rynek w Polsce 1944-1989 [Through the back door. Black market in Poland 1944-1989] Jerzy Kochanowski writes:

Although (...) the supply in Poland was not equally poor throughout the post-war period, it was never possible to achieve market balance, the crucial factor for eliminating black market [Kochanowski J. 2015: 52].

Therefore, this peculiar and often mythical black market within the economy of socialist Poland was the area where citizens tried to improve their financial situation and living conditions in a variety of ways. At the same time, engagement in black market activities meant violating the law, turning those involved into financial criminals.

\section{GOODS IN THE BLACK MARKET}

Each new administration brought amendments to the existing legislation concerning various sectors of the economy. In the first years after the war and in the Stalinist period of the 6-Year Plan, the law was most restrictive, but in the second half of the 1950s, with the permission to trade in agricultural goods, a part of the black market turned legal. Thus, some financial criminals became allies of the authorities in their efforts to provide better supplies for the average Polish family. However, throughout the period of centrally planned economy, some goods, freely available in a normal economy, were strictly controlled by the communist state. Depending on the economic situation in Poland, the assortment of these goods varied. One might say that Western currencies (dollar, pound, frank, German mark), gold and jewelry were typically tied for the first place on the list.

Other goods desired by Poles, but in constant shortage in socialist Poland, were luxury food products and knitwear. As mentioned before, the situation in this respect varied depending on the current attitudes of central authorities to those goods, and sometimes even on the personal taste of the First Secretaries. There were of course periods when basic food products, like bread, butter, meats (the cheapest ones), tea or sugar (especially in the years 1953-1954 or in the early 1980s, the time of the biggest crisis) also had to be added to the list. Then there were goods that the average family needed to live a normal life, like furniture, washing machines, fridges etc. The availability of these products in the regular market also 
varied depending on the period. Trade in goods which were outside of the official network of distribution increased particularly during the construction market boom of the early 1970s. Next, there were automotive products and consumables: petrol, oils, spare parts. Demand for these goods grew as Poles were opening up to the automotive market. Of course, in the 1940s, 1950s and 1960s, average citizens satisfied their needs in this respect by purchasing bicycles, mopeds or motorcycles by Polish manufacturers, but the 1970s were a time of a real automotive boom. Therefore, demand appeared in the black market for automotive products unavailable on the official market.

Finally, there were goods related to culture, both the so-called high culture and mass culture: books, concerts, film or music festivals, and press titles shaping the public opinion.

\section{THE SHADES OF THE BLACK MARKET}

Let us refer to the work of Jerzy Kochanowski once again. He emphasizes that centrally planned economy, and especially the market where both the citizens of the communist state and national companies purchased the goods they needed, had in fact many shades, and comprised several layers and a dozen or so elements [Kochanowski J. 2015: 12-14].

The first, legal layer was the so-called "red market", i.e. the fully legal network of distribution managed by the state. In Poland, as a result of "battle for trade" of 1947, the state took over the totality of wholesale and retail trade in all basic food products. This trade fell within the authority of the Ministry of Internal Trade. This first element was supported by the "pink market" - the network of second-hand shops created by the state. In socialist Poland, this was a network of legally operating retail outlets where citizens could sell their private property, e.g. clothes, valuables, furniture, works of art, or items brought from foreign trips. In the first period of their existence, both the seller and and the buyer had to provide their personal information, and the state set price caps for these goods. This type of outlets was supposed to complement the internal market with regard to luxury goods. On the other hand, central authorities wanted to control this sector, as they were aware that without control, these shops could quickly turn into places were stolen goods were handled. Also, by controlling sellers in second-hand shops, the authorities could track the commercial 
activities of those who could travel abroad. The third element of the legal market can be labeled the "white market", and its role was to complement the red and the pink markets. The "white market" operated in urban and rural marketplaces and market squares, where citizens could sell both used products, and home-grown food. This part of the official market was completely free - prices of products, especially food, were regulated by supply and demand. In harbor and border towns, one could also buy the so-called colonial goods - spices, cocoa, coffee (even green coffee for roasting), chocolate from various parts of the world, chewing gum, citrus fruits, and even pineapples.

The second layer of the market in socialist Poland can be labeled the "gray market". As J. Kochanowski points out, this was a combination of various small markets operating on the brink of legality. These included unregistered services provided by many professionals (builders, tailors, shoe makers or carpenters), but also flat rental, private tutoring, private medical services - all provided without official contracts and registration. There was also barter - cashless exchange of goods and services between national companies, which allowed them to accomplish the goals imposed by central production plans. Supply departments in companies had a certain amount of finished goods set aside for this purpose, exchanging them for necessary materials and parts [Kochanowski J. 2015: 13].

Beside the legal and semi-legal markets, in the socialist economy there were transactions conducted entirely outside of the system. Researchers of the state-controlled economy have identified at least two different elements in this layer as well. The first one was the "brown market" - the illegal redistribution of goods for which demand exceeded supply from the legal state-controlled "red market" (meat, clothes, white goods, construction materials etc.). The parties to the transactions did not try to make any additional profit, but instead satisfied their basic needs, based on reciprocity between people having access to different goods. The second one was the actual "black market", where goods obtained illegally (by theft, smuggle, embezzlement, or appropriation) from the legal markets were sold for profit, and the money was often invested in commodities which were considered safe, e.g. gold, dollars, works of art or real estate [Kochanowski J. 2015: 14]. So, the "black market" in the socialist economy was not actually entirely and completely black. However, it was surely the place where average Poles tried to find the goods which could not be found in the white or red markets, but for which they could pay with what they had - be it their own work, contacts, resourcefulness, or what they manufactured. 


\section{WHERE FROM AND WHERE TO? - WHERE AND WHEN?}

\section{YEARS 1945-1956}

Depending on the economic situation and the severity and effectiveness of the anti-speculation provisions functioning in various periods of socialist Poland, the citizens could participate to a greater or lesser extent in illegal economic activities (according to laws of the time), thus becoming a part of the black market.

The first years of the new system were also the years of post-war poverty and shortages of basic commodities. Although a system of rationing cards was in place, and although authorities set price caps on food products, these were hard to obtain for average citizens due to small supply. Because e.g. the bread price set by the state authorities was only $1 / 30$ of the free market price, and for other products the price difference could be even 1 to 50, the market situation simply encouraged people to engage in black market activities. Those who were more entrepreneurial, and had the experience and contacts from the time of occupation, could exploit the situation to make deals of a lifetime.

There was no way to stop it. Neither the Main Office for Fighting with Usury and War Speculation [AAN, URM (The Archive of New Files, The Council of Ministers' Office), 5/31, 5/252] created in 1944, nor the Special Commission for Fighting with Fraud and Economic Abuse created in November 1945 and operating until 1954 were capable of stopping black market transactions among the desperate members of society [APP (National Archive in Poznań), KSdWzNiSzG - DwP (Special Commission for Fighting with Fraud and Economic Abuse - Poznań branch), Miłosz J., Wstęp do inwentarza (Introduction to inventory)].

Where did the goods, crucial for satisfying the needs of the urban population (devastated by the war and chronically suffering from shortages of food and products needed to rebuild their houses) and of the rural residents, who had food products for exchange, but often needed tools and livestock in order to enable their farms to function, come from? One can map the flow of goods into particular markets in those first years. Big cities, like Warsaw, Poznań, Łódź or Krakow, were absorptive markets for food producers and traders from all over the country. The goods, especially agricultural products and meat, were also redistributed in their internal markets [APP, KSdWzNiSzG-DwP, f. 66]. Apart from that, citizens also need- 
ed other goods which the official market could not supply or supplied in minimum quantities. Here, again, one might look at the archive materials drafted by the Main Commission. These products included tea, washing powder, thread or yarn, among others [APP, KSdWzNiSzG-DwP, f. 90].

The post-war years were also a time of great migration. The western and northern lands incorporated into Poland opened new areas for black market operations. The displacement of Germans from those areas, and settlement of Poles repatriated from the eastern territories of the Second Polish Republic, created a very specific place for people with "initiative". German goods left in those territories were considered abandoned by the law, and thus became the property of the Polish state, but were often left with no supervision whatsoever. People living in areas neighboring the Wrocław, Zielona Góra, Szczecin or Olsztyn regions, called these territories the "Wild West". Reports drafted first by county delegates and later by county governors and sent to regional offices feature many descriptions of the behavior commonly referred to as looting [APP, County government in Skwierzyna 1945-1950, f. 58]. Organized groups which had the right means of transport took from abandoned houses everything they could sell in the towns of central Poland, e.g. furniture, clothing, machines, china, and even pipes and bricks. National administration and security authorities were helpless. One of the methods of fighting with this problem involved prohibiting those repatriated into these territories from moving, so that they could not loot the property assigned to them, and then move further down to the west to new households [Dulczewski Z., Kwilecki A. 1962: 90].

This type of crime started to decline with time, as more and more western and northern territories were populated. Also, the strengthening of the Polish administration, Citizens' Militia and security authorities, and the displacement of Germans meant that in the early 1950s, the problem was no longer mentioned in reports by local authorities.

In border areas - especially in the south of the country, but also in port towns, Poles found new ways to acquire goods which could complement the small and unappealing assortment of goods available on the modest local markets. In these areas, smuggling and illegal exchange of goods were always present, regardless of the political system. Even the turn of 1950s did not stop the exchange of goods in Polish port towns, such as Gdynia, Gdańsk and Szczecin. As a result of the post-war demographical changes, people who had nothing to do with marine economy came to Pomerania and quickly adapted to new conditions and possibilities. Luxury prod- 
ucts brought on ships, such as coffee, tea, chocolate, cocoa, clothing and gold, found buyers both locally and further inland, especially in the capital [Sobczak I. 1992: 23-25]. Meanwhile, in the border areas in the south of Poland, the sector which flourished first in the 1940s was illegal emigration - the trail went through Lower Silesia and Czechoslovakia to Austria and Western Europe. In the opposite direction, people brought mainly currency, gold, and products that were chronically lacking in Poland: shoes, leather goods, rubber and leather products [Porębski S. 2013: 263].

Immediately after the end of war and the stabilization of the system, the communist state tried to fight both with smuggling and with possession and sale of foreign currencies by the citizens - according to the Decree on Fiscal Crime of 1947 [Journal of Laws 1947, no. 37, item 140] and the Act on Currency Crime of March 1952, such sale was forbidden and punishable with severe penalties [Journal of Laws 1952, no. 21, item 134].

Although the fight with illegal markets in the years of the 6-Year Plan and the Stalinist terror was fiercer, they were impossible to eliminate in Poland. Furthermore, in December 1954, the decree of the Polish Council of State dissolved the Special Commission for Fighting with Fraud and Economic Abuse, and its cases were transferred to regional courts. This was justified by the decrease in the number of financial crimes [APP, KSdWzNiSzG - DwP, Miłosz J., Wstęp do inwentarza (Introduction to inventory)]. This happened during the implementation of the quick industrialization plan, a year after the largest crash in the food market [Jastrząb M. 2004: 48]. Two years later, in April 1956, the Polish parliament adopted the Amnesty Act, which stipulated in section 1(6) that:

[...] all crimes for which punishments were imposed by the former Special Commission for Fighting with Fraud and Economic Abuse are forgiven and forgotten [Journal of Laws, 1956, no. 11, item 57].

YEARS 1956-1970

The political and economic transformations started in October 1956 led to changes in citizens' income and increased their consumer capabilities. This resulted in an increase in real wages by almost $20 \%$ in the years $1956-$ 1957, which in turn increased demand for various products: not only food, but also those previously available only in controlled sale, such as radios, motorcycles or delicatessen products. At the same time, the authorities allowed for the reemergence of a private sector in services and trade, trying 
to make the selection of products available on the market bigger and more attractive [Kochanowski J. 2015: 74-75].

Acquiring raw materials, resources, and machines for the private sector was difficult, and was often achieved through common theft or more sophisticated actions. For example, when national companies disposed of equipment and waste products, these were later repaired or repurposed by craftsmen and could be still used. Private manufacturers had difficulties accessing national and cooperative distribution networks, but by acquiring the so-called "contacts" and corrupting the right people, these small manufacturers, traders and restaurant owners could also become successful [Kochanowski J. 2015: 75].

Beside the redistribution of goods and semi-finished products acquired from national and cooperative sources, the 1950s and 1960s were also the time of flourishing illegal trade in foreign currencies and smuggle of luxury goods, foods and clothing, as well as gold and jewelry. As Krzysztof Madej points out in the article Wszyscy byliśmy przemytnikami. Obraz przestępczości przemytniczej i dewizowej w latach 1956-1970 [We were all smugglers. Smuggling and currency-related crime in the years 1956-1970], more opportunities for foreign trips for the citizens of the communist state led to a quick increase in these crimes and, consequently, the development of the part of the black market dependent on the influx of goods from outside of the national economy [Madej K. 2008: 121-140]. Obtaining goods and currency from abroad in individual transactions was banned and subject to severe punishments throughout the socialist period in Poland. Even the post-October liberalization did not change legislation in this respect. Only the year 1960 brought a new Act on Fiscal Crime [Journal of Laws 1960, no. 21, item 123], which somewhat alleviated sanctions for currencyrelated crimes and trade in minerals (i.e. buying and selling them outside of the state-controlled market), which were punishable with up to three years in prison. In 1963, the punishment was increased to up to five years in prison [Journal of Laws 1963, no. 28, item 167]. These punishments remained in force until the act was amended, that is until 1972.

Although currency and smuggled goods mainly came from capitalist countries, goods and currency from other socialist democracies were also increasingly sought in the black market. This was caused by the fact that Poles could easily travel to East Germany, Czechoslovakia, Hungary, Romania, Bulgaria or USSR, both for tourism and for professional purposes. Both workers and party and youth activists who went there, apart from fulfilling their official tasks, were also busy trying to access better supplied 
or cheaper markets. Already in that early period gold, toys, furs and luxury spirits were brought (smuggled) from trips to the USSR. Trips to our southern neighbors offered an opportunity to buy sweets, clothing, shoes, luxury spirits and artificial jewelry, very popular in Poland in the 1960s and 1970s [Madej K. 2008: 122-123].

The increase in tourist trips to other socialist countries was stimulated by several factors: signing an agreement concerning tourist movement with Czechoslovakia in 1960 and with East Germany on January 1, 1963, and lifting the visa requirements for tourists traveling to Hungary. In the 1960s only, the number of tourist and trade trips grew from 250,000 to over 700,000 . But the Polish black market was supplied not only the the Poles bringing goods from abroad, but also by visitors from neighboring countries. In 1965, 510,000 tourists left from Poland to the Eastern bloc countries, while 500,000 came to Poland, but in 1968, the proportions changed and only 635,000 Poles left, while 1,487,000 people from the Eastern bloc came to Poland [Sowiński P. 2005: 285-288]. The increase in tourist traffic and the possibility to make extra money or at least to obtain goods not available on the Polish market resulted in the development of yet another sector of the black market - organizing tourist trips. Individual trips were rare at the time, for a very simple reason - few individual vehicles were available. As the 1969 statistical yearbook points out, the number of tourist or business trips to Western countries by Poles increased in the second half of the 1960s from 50,000 to almost 100,000, and at the same time Poland was visited by almost 200,000 Western citizens annually [Statistical Yearbook 1969: 501].

Depending on fashion and demand, these tourists brought, apart from currency and gold, the following luxury goods: watches, polyamide jackets, expensive spirits, jewelry, small white goods and small transistor radios. Repatriates' right to bring their foreign property to Poland, especially in the case of repatriates from the West, also enabled people to bring semi-finished products for manufacturing spices, clothing, fake furs and cosmetics.

The black market of the period of "small stabilization" focused on local goods and products, especially food and basic commodities. This can be evidenced by the types of sectors involved with financial scandals detected by national authorities. Apart from currency- and smuggle-related scandals, the type most often revealed and used for propaganda purposes were meat scandals of various sizes. Beside the biggest one, which ended with capital punishment for Stanisław Wawrzecki, the director of the 
Warsaw Municipal Meat Trade Company, there were also local scandals. One such scandal was detected in Poznan - people involved were, apart from the employees of a slaughterhouse in Poznan, the officers of the local Security Office supposed to supervise this sector of the industry [Twarze poznańskiej bezpieki - katalog wystawy (Faces of the Poznan Security Office the exhibition's catalog) IPN (The Institute of National Remembrance), 2007].

\section{YEARS 1970-1980}

At the beginning of the next decade Poles entered a whole new world. Władysław Gomułka was no longer in power. The Polish United Workers' Party Central Committee transferred the power to Edward Gierek and his administration, which entailed a change in attitudes of the people governing Poland towards financial policy. The new First Secretary of the Polish United Workers' Party Central Committee and his people looked up to the economies of capitalist countries, but also some communist states, such as Hungary, East Germany or Czechoslovakia, and tried to alter their economic goals. The new development strategy assumed the introduction of new technologies to the Polish economy to revive the Polish industry both the so-called heavy industry and the branches necessary for the daily lives of Poles, like construction, clothing, food, electronics and automotive. Apart from focusing on these goals, the authorities tried to make average citizens aware of the purchasing power of their wages which started to increase fast, particularly in the first half of the decade. Poles started to buy goods which they could not afford before or which required long-term saving, such as washing machines, fridges, television sets, new furniture and carpets. The consumerism in which Poles indulged in the early 1970s met a simple obstacle in subsequent years - namely, supply ceased to increase, but demand was still unsatisfied. Additionally, an increase in prices was blocked in 1971, which did not allow for the authorities to steer the increasing demand [Kochanowski J. 2015: 96-98].

From the moment the supply of goods actually crashed in the mid1970s, the black market developed again, involving a very large part of society. The most visible part of the black market, involving goods everyone needed in daily life, was the meat products market. Although from 1973, there were no more compulsory deliveries, and the authorities started to introduce a new system for sourcing agricultural goods from individual farmers (the so-called contracting) as early as 1974, some types of meat 
products started to lack in the market [Zaremba M. 2003: 198]. The society was forced to acquire these products in other ways, for example by visiting families living in the countryside, buying meat directly from farmers they knew personally, or trying to make contacts in butchers' shops. Even the creation of a network of shops offering so-called commercial prices (an attempt to introduce free prices shaped by the market) in the second half of the 1970s failed to even partially meet the demand. Financial means and awoken needs were huge.

Other products which formed a part of the black market folklore were: sugar (rationed since 1976), petrol, and spare parts for a growing number of "small" (126p) and "big" (125p) Fiat owners [Kochanowski J. 2015: 97]. ${ }^{2}$ The illegal market for petrol and spare parts, supported by many employees of the national companies who had access to company fuel pumps, and skillfully "managed" the fuel tanks of company cars, was quite well supplied at that time [Kochanowski J. 2015: 97].

Also, the fulfillment of social promises made by the Gierek administration, for example the quick increase in residential construction using the large panels technology, apart from being an attempt to solve a great problem with availability of new flats, generated new problems in the imbalanced internal market [Jarosz D. 2008: 1-3]. Access to white goods, furniture, carpets, curtains and similar products was indispensable. Of course, in the first half of the 1970s, the shortages were not that noticeable yet, especially since many families moving to new flats brought the equipment from the old ones. In the second half of the decade though, the shortages in the home equipment market were much larger, and even industry and trade could not satisfy the growing needs. With the right contacts and cash, it was possible to buy the most urgently needed goods in the black market, or from people in privileged professions who had access to them.

The authorities were aware of the disastrous state of economy, but at the same time they wanted to acquire currency to handle debt, so they needed any amount of the so-called hard currency. Therefore, looking at resourcefulness of the citizens conducting their own foreign trade and illegal foreign currency transactions, they decided to take at least partial control over this market. The operations conducted in the early 1970s by the Citizens' Militia and the Security Office, targeting the currency black mar-

2 In the 1970s, the number of individually-owned cars grew from 453,000 in 1970 to 2,069,000 in 1979. 
ket, were gradually discontinued, and illegal currency traders virtually became an institution tolerated by the authorities.

Even before the change of administration in April 1970, the Ministry of Finance adopted a resolution which in fact allowed for legal possession of foreign currency, as long as it was kept in special currency bank accounts. For currency means of registered origin (e.g. earnings from foreign contracts, per diems, sailors' and fishermen's remuneration), there were special accounts with an " $\mathbf{A}$ " symbol; for means of unregistered origin, accounts with a "B" symbol were kept [Monitor Polski 1970, no. 11, item 190]. The " $\mathrm{A}$ " accounts allowed the owners to freely manage their means, including taking them abroad. In the case of currency of unregistered origin, kept in " $\mathrm{B}$ " accounts, it could be spent in the so-called internal export transactions. Additionally, currencies kept in these accounts for three years became legal means for all transactions. These actions of the authorities meant that until the mid-1970s only, Poles gathered a total of 125 million dollars in currency accounts. Despite currency trade still being illegal, the authorities' actions allowed for the gradual legalization of illegal currency possessed by citizens. The "Pewex" Internal Export Company was created in 1974, and was supposed to give citizens the possibility to spend this money on luxury goods, e.g. flats and cars, outside of the official waiting list system.

In 1976, the authorities estimated that citizens still had much more unregistered currencies, and further liberalized the currency trade by closing down all the " $\mathrm{B}$ " accounts - from this moment on, all currency accounts were " $\mathrm{A}$ " accounts. The authorities no longer asked where you had your dollars from, but wanted these dollars spent in their shops and kept in the PEKAO national bank [Monitor Polski 1976, no. 38, item 173]. Due to similar actions in the late 1970s, savings in the amount of almost $500,000,000$ dollars were collected. How much more there was in citizens' pockets, we will probably never know. The fact remains that the currency black market faded a little bit, becoming more gray and evolving towards white. Adverts such as "Vouchers for sale" in the press were to be understood as "Currency for sale". A different side of this market was trade in Pomerania, conducted by sailors, fishermen and their families, and based on the "Baltona" company which at first supplied luxury products and food to Polish ships, and from the 1970s, also to individual clients from this group. In "Baltona" shops, products were bought for friends, relatives and their friends, for dollars collected in the so-called "sailors' books", and then settled at black market dollar prices. 
Those who had access to deficit products and services could offer them in return for other scarcely available goods and services. One must remember then every year this category included more and more goods.

\section{YEARS 1981-1989}

The 1980s - the period of the first "Solidarity" movement, martial law and attempts by Messner's administration to reform the economy - were a time of great crisis. In this period, the black market was the institution on which the citizens of the late socialist Poland relied every day, and which allowed to maintain a decent living standard. The symbol of the period were ration cards "for everything", which were supposed to provide at least a minimum supply of basic food products.

Ration cards for sugar, as it has been mentioned, were introduced in mid-1976, but the social pressure and strike demands from August, 1980 led in April, 1981, to the introduction of a ration card system first for meat and meat products, and then for other goods, such as fats, grains (barley, oat, flour), hygiene products (soap, shampoos, washing powders, toothpaste), chocolate products, cigarettes and alcohol. In the late 1981, there were even vouchers (cards) for shoes. All citizens' IDs included the socalled "mother-card" or "card for cards", in which all the received ration cards were recorded. [Szymańska K. 2009]. A non-exhaustive list of cards and vouchers (included below) used in the 1980s is truly impressive:

Table 1. List of types of ration cards used in the 1970s and 1980s

\begin{tabular}{|l|l|l|l|}
\hline \multicolumn{1}{|c|}{$\begin{array}{c}\text { Cards for sugar } \\
\text { 1976-1985 }\end{array}$} & \multicolumn{1}{|c|}{$\begin{array}{c}\text { Cards for meat } \\
\text { 1981-1989 }\end{array}$} & $\begin{array}{c}\text { Cards for petrol } \\
\text { [1982] 1984-1989 }\end{array}$ & $\begin{array}{c}\text { Other cards and } \\
\text { vouchers }\end{array}$ \\
\hline $\begin{array}{l}\text { Year 1976: } \\
\text { C-1 and C-2 type } \\
\text { cards }\end{array}$ & $\begin{array}{l}\text { D type card for } \\
\text { meat from June } \\
1981\end{array}$ & $\begin{array}{l}\text { Cards for petrol - } \\
\text { 1982 - stamped }\end{array}$ & "Card for cards" \\
\hline $\begin{array}{l}\text { Year 1981 - } \\
\text { sugar and soap }\end{array}$ & $\begin{array}{l}\text { B type card for } \\
\text { meat from August } \\
1981\end{array}$ & $\begin{array}{l}\text { Type 2 card for } \\
\text { petrol - 1983 }\end{array}$ & 0 type cards: \\
\hline $\begin{array}{l}\text { Year 1982 - } \\
\text { BD card - sug- } \\
\text { ar, soap, washing } \\
\text { powder }\end{array}$ & $\begin{array}{l}\text { M-I type cards for } \\
\text { white collar work- } \\
\text { ers }\end{array}$ & $\begin{array}{l}\text { Type 3 card for } \\
\text { petrol - 1984 }\end{array}$ & $\begin{array}{l}\text { P-1 cards (for } \\
\text { flour, cereal prod- } \\
\text { ucts, soap, wash- } \\
\text { ing powder, } \\
\text { sweets) }\end{array}$ \\
\hline
\end{tabular}




\begin{tabular}{|c|c|c|c|}
\hline $\begin{array}{c}\text { Cards for sugar } \\
\text { 1976-1985 }\end{array}$ & $\begin{array}{l}\text { Cards for meat } \\
1981-1989\end{array}$ & $\begin{array}{l}\text { Cards for petrol } \\
\text { [1982] 1984-1989 }\end{array}$ & $\begin{array}{c}\text { Other cards and } \\
\text { vouchers }\end{array}$ \\
\hline \multirow[t]{5}{*}{$\begin{array}{l}\text { Year } 1982 \text { - } \\
\text { BD card - sug- } \\
\text { ar, soap, washing } \\
\text { powder }\end{array}$} & $\begin{array}{l}\text { M-II type cards for } \\
\text { blue collar work- } \\
\text { ers }\end{array}$ & $\begin{array}{l}\text { Type } 4 \text { card for } \\
\text { petrol - 1985-1988 }\end{array}$ & $\begin{array}{l}\text { P-2 type cards (for } \\
\text { flour, cereal prod- } \\
\text { ucts, sweets, alco- } \\
\text { hol and cigarettes) }\end{array}$ \\
\hline & $\begin{array}{l}\text { M-II-K type card } \\
\text { for pregnant } \\
\text { women }\end{array}$ & $\begin{array}{l}\text { Permission to buy } \\
\text { extra petrol }\end{array}$ & $\begin{array}{l}\text { P-3 type cards (for } \\
\text { flour, cereal prod- } \\
\text { ucts, sweets, alco- } \\
\text { hol and cigarettes) }\end{array}$ \\
\hline & $\begin{array}{l}\text { M-I type - for pro- } \\
\text { fessional soldiers }\end{array}$ & & Card for shoes \\
\hline & $\begin{array}{l}\text { M-I-D type cards } \\
\text { for children }\end{array}$ & & $\begin{array}{l}\text { "Card" for wed- } \\
\text { ding bands }\end{array}$ \\
\hline & & & $\begin{array}{l}\text { Child's medical } \\
\text { record book with } \\
\text { information on } \\
\text { food purchases } \\
\text { and issues of the } \\
\text { Lugol solution }\end{array}$ \\
\hline
\end{tabular}

Source: Szymańska K. 2009.

Just like other products considered valuable and exchangeable, also cards became an illegally traded commodity. The printing and distribution system was not too secure, therefore one could acquire them from outside of the formal distribution. Thanks to that, it was possible to obtain more goods than one's ration. Some of the goods obtained this way ended up in the actual black market, where people who had a product tried to sell it to make extra money to patch up their budgets or exchange it for some other product they needed. The system itself did take into consideration the possibility of exchanging cards, for example cards for alcohol could be used to buy sweets or cigarettes. Similarly, one could buy alcohol with cards for cigarettes.

Next to the card system there were also mechanisms (thefts from plants, warehouses, and shops) related to the exchange of those goods which were most urgently needed outside the system, namely meat, sugar, fats (butter, lard, oil) or sanitary goods. Additionally, there was also trade in alcohol (of more or less legal origin), which at this difficult time was a natural means of exchange. Even the introduction of martial law did not put a halt to black market. Famous "meat trips" reminded Poles of the 
period of occupation, and the army and Citizens' Militia patrols, which were supposed to search cars for illegal press, were also busy catching meat traffickers [Kochanowski J. 2015: 114-116]. As Jerzy Kochanowski points out: "No legal act, especially one increasing penalties, is capable of bringing back market balance" [Kochanowski J. 2015: 117]. Although from the mid-1980s shop shelves gradually filled with basic products, the goods which were in scarce supply were still rationed. The last ration cards (for meat) actually only disappeared after the centrally planned economy had crashed.

Apart from this additional layer of black market in socialist Poland, all the products which dominated in the previous decades were still present. People bought gold and jewelry as an alternative to the now almost nontransferable Polish PLN. Dollars and West German marks were also traded. Luxury food products were sought (Western spirits, coffee, chocolate and sweets), which were social status symbols that one could show off in front of friends. Even after the martial law had been lifted, clothes, photography equipment, white goods or sweets brought from other socialist countries were still sought and willingly bought.

\section{CONCLUSIONS}

The black market was a symbolic place for the citizens of the Polish People's Republic in the 1970s and 1980s, but also earlier. It allowed Poles to get a taste of a different world - a world they could not see on an everyday basis - but it was also the place where on could acquire things that could never be bought, even if they were wanted badly and worked hard for. To get, to arrange, to fix - these are the verbs which the generation of then thirty- and forty-somethings still use today interchangeably with "to buy". This was the space where laws of the time were ignored and very often violated. Back then, even those who set those rules were aware that, in the economic and legal system of the time, they could not satisfy the needs of society, which had been awoken especially in the 1970s.

This was also the place in which the new group of businessmen that emerged after 1990 had acquired their basic economic education and learned the rules of the free market. 


\section{BIBLIOGRAPHY:}

\section{PRINTED RESOURCES}

Journal of Laws of the Republic of Poland - 1947, 1952

Journal of Laws of the Polish People's Republic - 1960, 1963

Monitor Polski - 1970, 1976

Statistical Yearbook 1969, Warsaw 1969

\section{ARCHIVE MATERIALS}

The Archive of New Files (AAN) - Council of Ministers Office (URM), sign. 5/31, 5/252, The report of the Main Office for Fighting with Usury and War Speculation

National Archive in Poznań (APP): Special Commission for Fighting with Fraud and Economic Abuse - Poznań branch

APP - County government in Skwierzyna 1945-1950

\section{LITERATURE}

Dulczewski Z., Kwilecki A. (1962), Społeczeństwo wielkopolskie wo osadnictwie Ziem Zachodnich [Greater Poland society in settling the western lands], Poznań.

Handke W., Miłosz J., Zwiernik P. (2007), Twarze poznańskiej bezpieki - katalog wystawy [The faces of Poznań Security Office - exhibition catalog], IPN Poznań, http:/ / pamiec.pl/ pa/biblioteka-cyfrowa/katalogi-wystaw/9858/Twarze-poznanskiej-bezpieki.html [access on: 24.09.2016].

Jarosz D. (2008), Polaków drogi do mieszkania w PRL (szkic problemu) [How Poles got flats in socialist Poland (outline of the problem)], lecture given in the Professor Anna Żarnowska seminar (September 2008), www.historiaspoleczna.uw.edu.pl/seminarium/miastoprzestrzen-i-ludzie/polakow_drogi_do_mieszkania_w_PRL [access on: 24.09.2016].

Jastrząb M. (2004), Manewr gospodarczy? Korekta polityki ekonomicznej na IX Plenum Komitetu Centralnego PZPR w 1953 r. [Economic maneuvers? Amendment of the economic policy in the $9^{\text {th }}$ Plenary Session of the Polish United Workers' Party Central Committee in 1953], "Przegląd Historyczny" 94/1, p. 48, http://bazhum.muzhp.pl/media// files/ Przeglad_Historyczny/Przeglad_Historyczny-r2003-t94-n1/Przeglad_Historycznyr2003-t94-n1-s43-58/Przeglad_Historyczny-r2003-t94-n1-s43-58.pdf [access on: 17.09. 2016].

Kochanowski J. (2015), Tylnymi drzwiami. „Czarny rynek” w Polsce 1944-1989 [Through the back door. Black market in Poland 1944-1989], Warsaw.

Madej K. (2008), Wszyscy byliśmy przemytnikami. Obraz przestępczości przemytniczej i dewizowej w latach 1956-1970 [We were all smugglers. Smuggling and currency-related crime in the years 1956-1970], [in:] "Pamięć i Sprawiedliwość" no. 7/2 (13), p. 121-140.

Miłosz J. (1995), Wstęp do inwentarza zespotu Komisja Specjalna do Walki z nadużyciami i Szkodnictwem Gospodarczym - Delegatura w Poznaniu, [Introduction to the inventory of the Special Commission for Fighting with Fraud and Economic Abuse team - Poznan branch], Poznań.

Pick D. (2003), Fenomen prywaciarza w PRL. Warszawa w latach 1956-1970, [The phenomenon of private business in socialist Poland. Warsaw in the years 1956-1970], Warsaw.

Porębski S. (2013), Walka o wtadze na Ślasku Cieszyńskim w latach 1945-1947 [Fight for power in Cieszyn Silesia in the years 1945-1947], Katowice, http://www.sbc.org.pl/ Content/96285/doktorat3444.pdf [access on: 17.09.2016]. 
Sobczak I. (1992), Obraz demograficzny województw nadmorskich Polski w latach 1946-1990, Wybrane liczby $i$ tendencje rozwoju [Demographics in the Pomeranian regions of Poland in the years 1946-1990. Selected figures and development trends], Gdańsk.

Sowiński P. (2005), Wakacje w Polsce Ludowej. Polityka władz i ruch turystyczny (1945-1989) [Holidays in socialist Poland. Authorities' policy and tourist movement (1945-1989)], Warsaw

Szymańska K. (2009), Sklepy w czasach PRL [Shops in socialist Poland], Warszawa, http:/ / wiedzaiedukacja.eu/wp-content/uploads/2009/05/karolina-szymanska-sklepy-wprl.pdf, [access on: 21.09.2016].

Zaremba M. (2003), „Bigosowy socjalizm” Dekada Gierka, [Mixed socialism - Gierek's decade] [in:] Miernik G. [ed.] Polacy w PRL. Strategie przystosowawcze [Poles in socialist Poland. Adaptive strategies], Kielce.

Jan Miłosz - PhD, senior lecturer at the Economic History Department at the AMU History Institute in Poznan. His academic interests include local government, communal economy of the Polish Republic of People and economic and trade councils in the period of political transformation of 1989 and the first decade of 21st century. 